\title{
Fluoride Release and Uptake Capability of Glass-ionomer Cements and Compomers Used as Dental Restorative Materials
}

\author{
ZSIGMOND LORAND MAKKAI ${ }^{1}$, MELINDA SZEKELY2*, ZITA FAZAKAS ${ }^{3}$, LEVENTE MESTER NAGY ${ }^{1}$, KINGA MATYAS BARTA ${ }^{1}$, \\ BERNADETTE KEREKES MATHE ${ }^{2}$ \\ 'University of Medicine, Pharmacy, Science and Technology, Faculty of Dental Medicine, 38 Gheorghe Marinescu Str., 540139, \\ Targu Mures, Romania \\ 2University of Medicine, Pharmacy, Science and Technology, Faculty of Dental Medicine, Department of Morphology of Teeth and \\ Dental Arches, Technology of Dental Prosthesis and Dental Materials, 38 Gheorghe Marinescu Str., 540139, Targu Mures, Romania \\ 3University of Medicine, Pharmacy, Science and Technology, Faculty of Dental Medicine, Department of Biochemistry and \\ Environmental Chemistry, 38 Gheorghe Marinescu Str., 540139, Targu Mures, Romania
}

\begin{abstract}
Dental caries and secondary caries are the most common problems in dentistry. Many studies provided evidence for the anticariogenic effect of fluorides. The incidence of secondary caries is decreased in teeth restored with fluoride releasing materials. The purpose of the present in vitro study is to evaluate the fluoride release and uptake capability of two glass-ionomer cements and two compomers. A total number of 60 specimens were prepared according to the manufacturer's instructions using silicone molds. The specimens were transferred in plastic containers containing artificial saliva $(\mathrm{pH}=7)$, incubated at $37^{\circ} \mathrm{C}$ for $24 \mathrm{~h}$ and divided in three subgroups: control group, varnish treated group and dentifrice treated group. The fluoride ion content was measured on five times during a period of 30 days using an Orion $720 \mathrm{~A}$ fluoride meter with 9609 BN fluoride ion electrode. The self-curing glass-ionomer cement released the highest amounts of fluoride ions at the beginning and after the one month study period. The samples of the four materials tested in the varnish treated groups showed significant differences compared to their control groups on the second day. Dentifrice treated groups did not show significant differences compared to their control groups, except values measured after 30 days. Application of fluoride varnish produced an increase of fluoride release for the first $24 \mathrm{~h}$ in case of all materials. However, results suggest that the use of fluoridated dentifrice would be more effective in caries prevention due to their fluoride uptake capability.
\end{abstract}

Keywords: glass-ionomer, compomer, fluoride release, fluoride uptake, fluoride ion electrode

Tooth decay due to dental caries is one of the most common problems we can meet in dentistry. Another constant problem in restorative dentistry is the secondary caries. This is the reason why the role and the application area of fluorides $(F)$ is increased in the prevention of dental caries.

Many researchers have demonstrated the anticariogenic effects of fluorides. This effect has been reported widely in the scientific literature. The influence of fluoride content of different dental restorative materials on dental tissues has been studied by many researchers [1-3].

It is a fact that the severity and incidence of secondary caries are decreased in teeth restored with fluoride releasing materials. On the other hand, the topically used fluoride increases the fluoride content of the surrounding tooth structure which leads to the forming of fluorapatite crystals, which are more capable to resist to acid attack [4].

Studies have proved that fluoride ion release from restorative materials decrease with time, so in order to sustain their anticarious nature it is necessary a longer lasting and continuous capability of fluoride release. The anticariogenic effect depends on the material's ability to exhibit fluoride rechargability also [5].

Glass-ionomer cements (GIC) are dental restorative materials used in restorations where prevention of dental caries is the priority. This powder-liquid biocomponent system, from a chemical point of view, is a complex polyacrylate or glass poly-alchenolate [6-8].
GICs were evolved from silicate cements. Since the application of silicate cements, a significant decrease in secondary caries activity around these restorations was noticed [9].

Wilson and Kent were the first who introduced GIC in 1972. The GICs present a very good biocompatibility due to their fluoride releasing and absorbing abilities. They have a good adhesion to tooth structures, their pulp damaging effect is minimal and thanks to their fluoride releasing capability, they play a role in strengthening the tooth against secondary caries, thus presenting cariostatic and antimicrobial action [1, 2, 10, 11-15]. GICs are also used in young patients' permanent posterior teeth, where fast adhesion is required [16]. They have the advantage of being less sensitive to moisture than resin-based materials. When moisture control is a problem, GICs may be a potential alternative for resin-based materials [17-21].

In the late 1980s and early 1990s two new types of restorative dental materials were placed on market, the so-called 'light cured GICs'. Two different materials were introduced: the resin-modified GICs and the polyacidmodified resin composites [22].

The polyacid-modified resin composite is the dental compomer. The compomers were formed using composites and GICs, possessing most of the properties and characteristics of both materials. They function as acid buffers along the interface with the tooth structure, release fluoride ions continuously and have a good adhesion to dentine. They can be regarded as the alternative of

* email: melinda.szekely@umfst.ro; Phone: 0744878610 
aesthetic dental filling materials (GICs and composites) [22-25].

In Romanian Dental Medicine there are also other recent in vivo and in vitro experimental study, performed especially in the fields of implantology and endodontics [26-29].

The purpose of the present in vitro study is to evaluate the fluoride release and uptake capability of two different $\mathrm{GIC}$ and two different compomers.

\section{Experimental part}

\section{Materials and methods}

Four different restorative materials were used in this study. Two of the materials used were glass-ionomer cements: a self-curing (chemically cured) GIC and a lightcuring $\mathrm{GIC}$. The other two restorative materials were compomers (Table 1). For testing the fluoride release and uptake capacity 60 specimens were prepared, 15-15 pieces of each material, according to the manufacturer's instructions. The prepared materials were placed in silicone molds of $5.5 \mathrm{~mm}$ diameter and $2 \mathrm{~mm}$ height each. The materials placed in the molds were captured between two glass plates in order to eliminate the material excess and to obtain plain surfaces. The setting of the self-curing GIC (Glassfill) was complete after 5 minutes. The light-curing GIC (Securafil) and the compomer (Glasiosite, TwinkyStar) specimens were light-cured according to the manufacturers' instructions. After setting all specimens were removed from the molds and transferred individually in plastic containers containing $1 \mathrm{ml}$ of artificial saliva each.

The artificial saliva was prepared by adding $0.400 \mathrm{~g}$ natrium chloride, $0.400 \mathrm{~g}$ potasium chloride, $0.795 \mathrm{~g}$ calcium chloride monohydrate, $0.69 \mathrm{~g}$ sodium dihydrogen phosphate, $0.005 \mathrm{~g}$ sodium sulfide nonanhydrate and $1.0 \mathrm{~g}$ urea to $1000 \mathrm{~mL}$ distilled water. The $\mathrm{pH}$ was adjusted to seven. The containers were incubated and stored at $37^{\circ} \mathrm{C}$ for $24 \mathrm{~h}$.
The specimens in each group were subdivided into three subgroups: $A, B$ and $C$. The discs in subgroup $A$ were placed in artificial saliva for 30 days. The saliva was changed every day with fresh artificial saliva. The discs in subgroup $B$ were placed in artificial saliva and after $24 \mathrm{~h}$ of incubation ( $1^{\text {st }}$ day) the specimens were treated with fluoride varnish (Bifluorid 10, VOCO) for $1 \mathrm{~min}$ and rinsed with distilled water, then placed in fresh artificial saliva. The saliva was changed every day for a period of 30 days. The discs in subgroup $C$ were placed in artificial saliva, treated for 2 min daily with a fluoride containing dentifrice (Colgate, $1450 \mathrm{ppmF}$ ), rinsed with distilled water then placed in fresh artificial saliva for the same period of 30 days.

The fluoride ion content was measured with an Orion $720 \mathrm{~A}$ fluoride meter with $9609 \mathrm{BN}$ fluoride ion electrode. In the first step $1 \mathrm{ml}$ of artificial saliva was mixed with $1 \mathrm{ml}$ of TISAB II (Total Ionic Strength Adjustment Buffer) buffer solution. The TISAB II partially decomposes fluoride from polyvalentcations, consequently, making fluoride available for measurement. The fluoride calibration slope was checked using standard solutions between $0.1 \mathrm{ppm}$ and $10 \mathrm{ppm}$ fluoride. Previously three specimens of artificial saliva and three specimens of distilled water were tested to determine the baseline concentration of fluoride. These mean baseline concentrations w ere subtracted from each of the values obtained. The measurements were made on the $1^{\text {st }}$ day, $2^{\text {nd }}$ day, $3^{\text {rd }}$ day, $10^{\text {th }}$ day and the $30^{\text {th }}$ day.

The data were statistically analyzed using one-way ANOVA tests, independent and dependent t-tests (GraphPad InStat software).

\section{Results and discussions}

The mean fluoride ion release values in the control groups of the tested materials are shown in figure 1. Comparing the two GIC sample groups, the Glassfill showed significantly higher fluoride release values

\begin{tabular}{|l|l|l|}
\hline $\begin{array}{l}\text { Restorative } \\
\text { material }\end{array}$ & Material class & Manufacturer \\
\hline Glassfill & self-curing glass-ionomer cement & Schulzer, Germany \\
\hline & & Willmann\&Pein, \\
\hline Securafil & light-curing glass-ionomer cement & Barmstedt/Hamburg, \\
\hline Glasiosite & polyacid-modified resin composite (compomer) & Voco, Germany \\
\hline TwinkyStar & polyacid-modified resin composite (compomer) & VOCO, Germany \\
\hline
\end{tabular}

Table 1

MATERIALS TESTED FOR FLUORIDE RELEASE AND UPTAKE

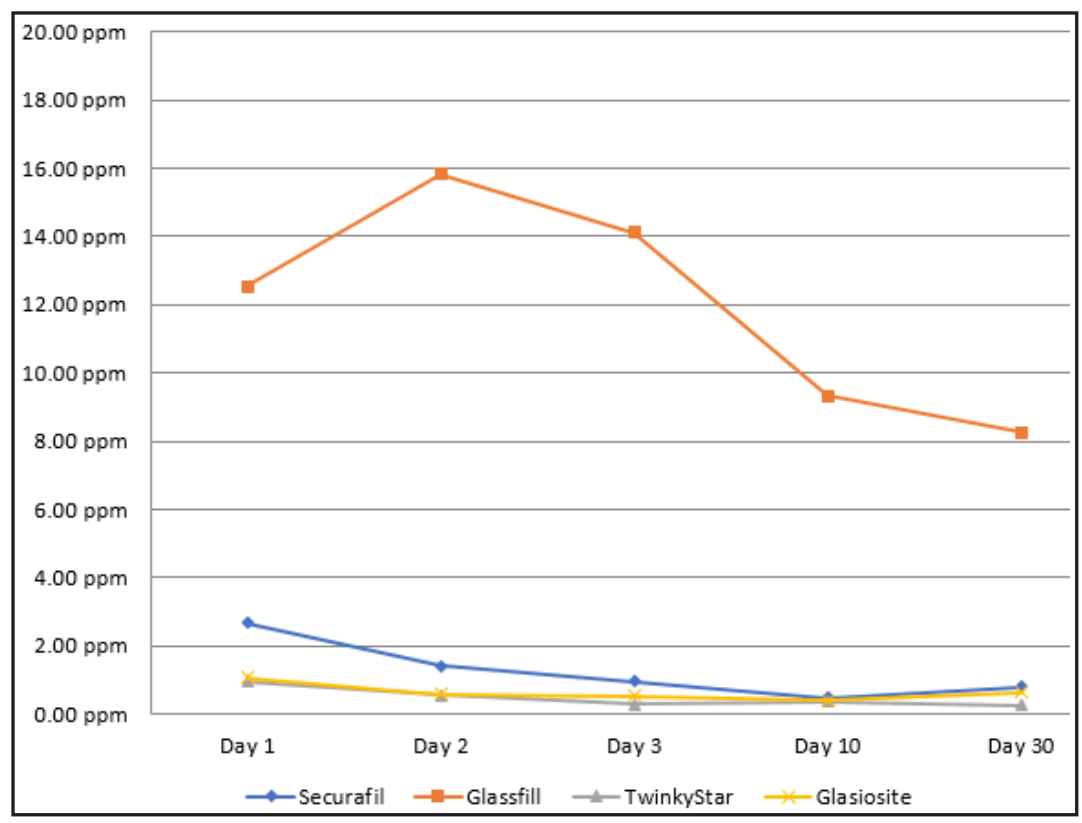

Fig. 1. Fluoride release in the control group of each material during the study period 
Table 2

MEAN VALUES OF FLUORIDE RELEASE GROUPED BY MATERIAL AND TREATMENT (ALL VALUES ARE EXPRESSED IN ppm)

\begin{tabular}{|c|c|c|c|c|c|c|}
\hline & & $\begin{array}{c}\text { Day } 1 \\
\text { (untreated) }\end{array}$ & Day 2 & Day 3 & Day 10 & Day 30 \\
\hline \multirow{3}{*}{ Securafil } & Control group & 2.66 & 1.41 & 0.95 & 0.47 & 0.79 \\
\hline & Varnish treated group & 2.91 & 67.42 & 8.93 & 0.93 & 1.09 \\
\hline & Dentifrice treated group & 2.83 & 1.56 & 0.98 & 0.57 & 1.36 \\
\hline \multirow{3}{*}{ Glassfill } & Control group & 12.53 & 15.82 & 14.11 & 9.33 & 8.26 \\
\hline & Varnish treated group & 17.06 & 49.12 & 24.8 & 7.02 & 7.57 \\
\hline & Dentifrice treated group & 14.5 & 15.28 & 13.53 & 6.6 & 7.92 \\
\hline \multirow{3}{*}{ TwinkyStar } & Control group & 0.95 & 0.547 & 0.27 & 0.36 & 0.24 \\
\hline & Varnish treated group & 0.58 & 129.75 & 7.22 & 0.45 & 0.46 \\
\hline & Dentifrice treated group & 0.65 & 0.53 & 0.32 & 0.38 & 0.94 \\
\hline \multirow{3}{*}{ Glasiosite } & Control group & 1.06 & 0.58 & 0.52 & 0.37 & 0.61 \\
\hline & Varnish treated group & 1.01 & 48.22 & 3.58 & 0.39 & 0.48 \\
\hline & Dentifrice treated group & 1.39 & 0.74 & 0.55 & 0.37 & 0.87 \\
\hline
\end{tabular}

$(p=0.00001)$. This self-curing material released the highest amounts of fluoride ions after the one month study period.

Differences among the mean fluoride contents, representing the fluoride release values of the four materials measured on the first day were statistically significant $(p=0.00001)$. Statistically significant higher values were found on the second day in the varnish treated groups (table 2), the highest values being in the TwinkyStar specimen group.

Varnish treated groups showed significant differences compared to their control groups on the second day, all the samples from the four materials tested having higher values of fluoride release. Regarding the varnish treated samples after, 24 hours from the treatment, the TwinkyStar samples were having significantly higher values than the other materials ( $p=0.0002$ ) (fig. 2).

Dentifrice treated groups did not show significant differences compared to their control groups, only after 30 days, when the Securafil $(p=0.025)$, TwinkyStar $(p=0.002)$ and Glasiosite $(p=0.026)$ samples were having significantly higher fluoride release values (Fig. 3).

Comparing the dentifrice and varnish treated groups, the Twinkystar $(p=0.01)$ and the Glasiosite $(p=0.01)$ samples were releasing significantly higher amounts of fluoride ions after 30 days.

Fluoride plays an important role in prevention of secondary dental caries and helps remineralization [30].

Basic researches have shown that a fluoride concentration of $2 \mathrm{mg} / \mathrm{L}$ inhibits the bacterial plaque formation and helps the formation of hydroxyfluoroapatite which is resistant to acid attack, thus inhibiting the formation of carious lesions [31]. Therefore several fluoride releasing restorative materials have been described and studied in the scientific literature. The most known and often used are the GICs and the compomers. Fluoride release is considered one of the most important qualities of GICs. The fluoride release of these materials has been presented in various studies using different research methods. Many laboratory trials compared the fluoride release of GIC with other restorative materials [5, 30, 3237]. Other studies showed that the fluoride release from GIC is a complex process. First, an initial dissolution process, a short-term reaction takes place when the readily soluble fluoride is released. The second mechanism is more gradual, it is a long-term and continuous release process [38, 39].

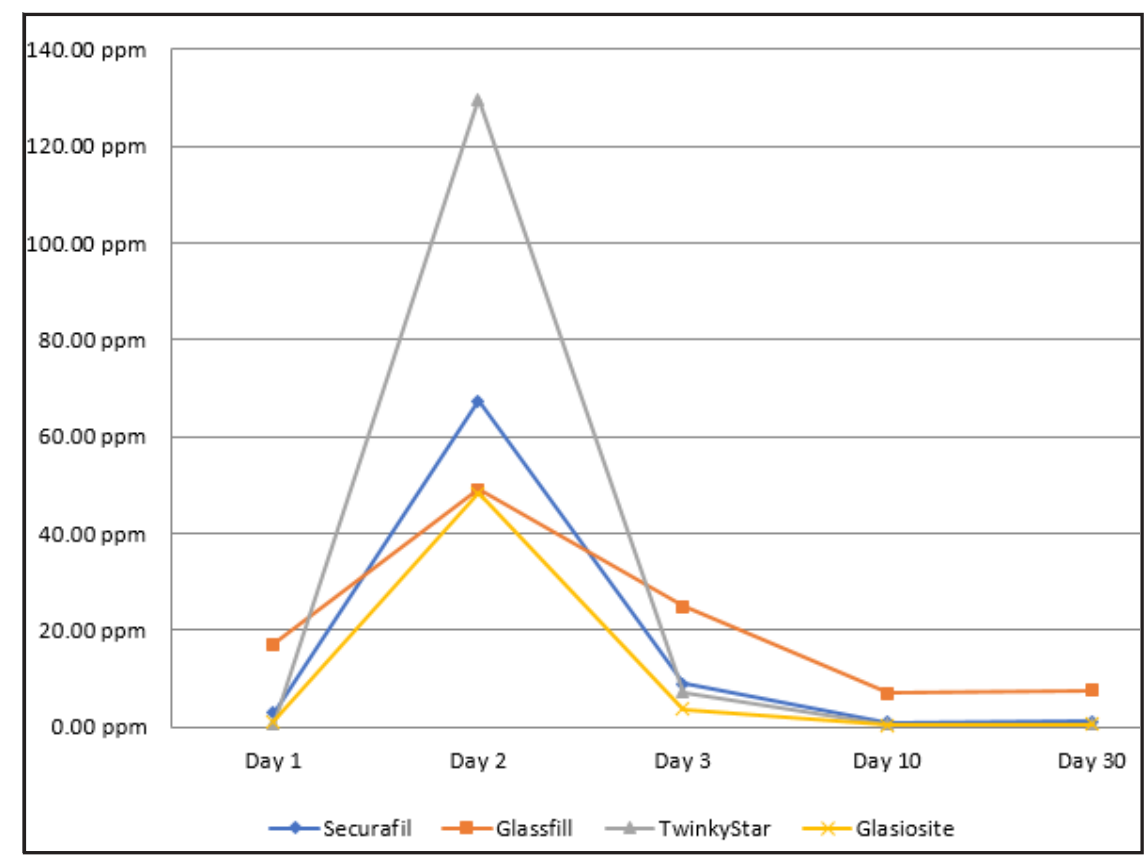

Fig. 2. Fluoride release in the varnish treated group of each material during the study period 


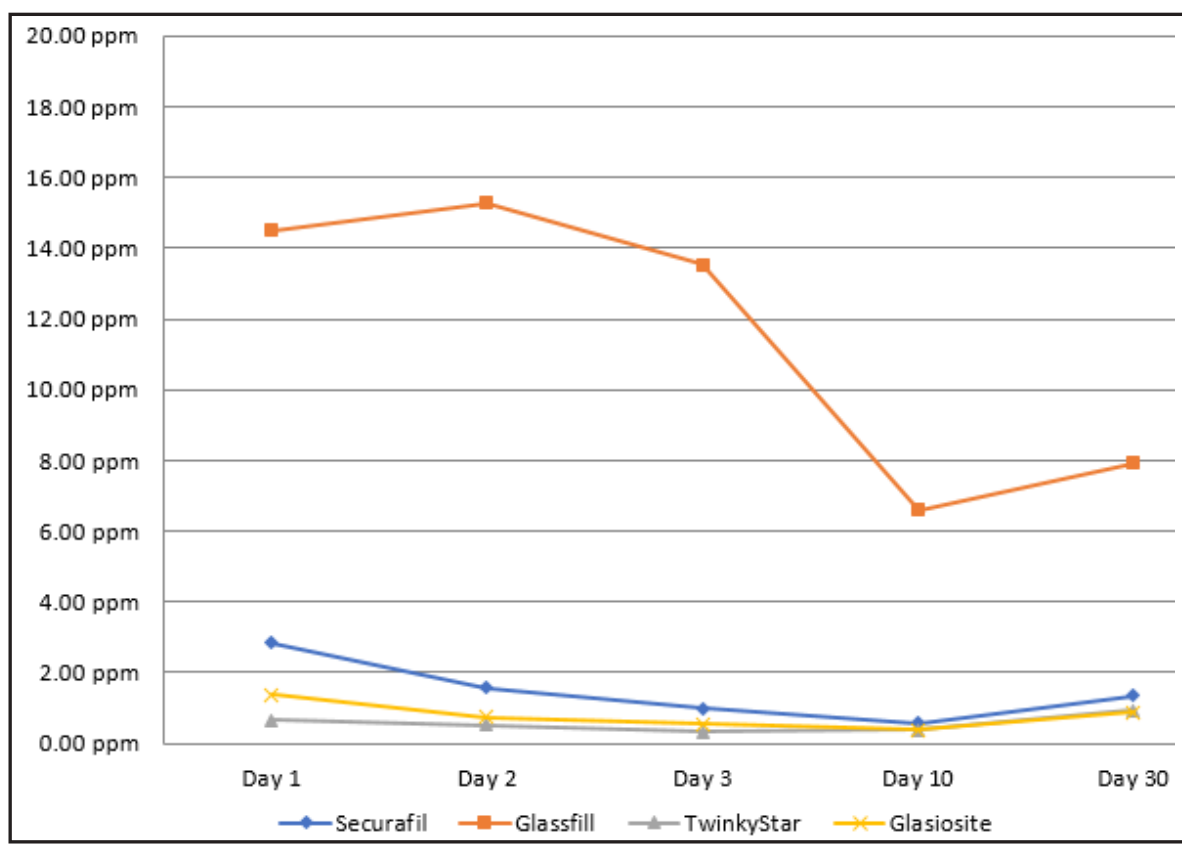

Fig. 3. Fluoride release in the dentifrice treated group of each material during the study period

In case of an in vitro research many factors influence the fluoride release and uptake. These could be the medium in which the specimens are stored, the temperature and the powder content of the material [40].

In the present study artificial saliva was chosen to simulate the natural oral environment and the human saliva, although it is impossible to simulate the properties of human saliva due to its unstable nature. In this medium the fluoride release properties of GIC and compomer restorative materials were studied for a period of 30 days. In order to evaluate the fluoride uptake capacity of the materials, treatment with fluoride varnish and fluoride containing dentifrice was used.

A control group was assigned for each material. Observing these control groups, the fluoride release of the two $\mathrm{GICs}$ used in the study were the highest on the $1^{\text {st }}$ day, after that a continouos decrease was shown until the $10^{\text {th }}$ day. The release activity was stable between days 10 and 30, while a slight increase was seen at the end of study period. Therebyithas been demonstrated the phenomenon of initial burst. These results are similar to the results of earlier studies from the scientific literature $[36,41]$.

On the other hand the specimens of the two compomer materials from the control groups did not show any increases in fluoride release activity during the study. This is in agreement with previous studies where other compomer products were tested [33, 42].

However, there were studies where compomers showed high initial fluoride release values, this property was material-dependent [43]. In the present study the mean fluoride release values measured in the self-curing GIC (Glassfill) group were significantly higher than those in the light-curing GIC (Securafil) group. The two compomer groups were also showing a significant difference, the Glasiosite samples were releasing more fluoride.

The highest values of fluoride release were measured on the $2^{\text {nd }}$ day in the specimens treated with fluoride varnish, followed by a continuous decrease until the $10^{\text {th }}$ day, after that the release activity was stabilized. Fluoride varnish increased the fluoride release for a short time, and this finding is in agreement with earlier studies [3, 36, 44, 45].

The Securafil restorative material is a light activated twocomponent GIC. By the diffusion of sufficient water, the fluoride ions are entered and firmly encapsulated in the polyacrylate matrix. It can be assumed from the present study that in this material, the fluoride ions encapsulated by the matrix decelerate the fluoride release rate, which might be slower and lower than in the self-curing GIC.

The specimens treated with fluoridated dentifrice did not release significantly more fluoride at the beginning compared to the specimens from the control groups. Significantly higher values were measured only after a month in case of the light-cured GIC (Securafil) and tested compomers (Glasiosite and TwinkyStar). Similar results were found in earlier studies $[5,33,46]$. This could be a possible result of fluoride uptake of restorative materials from the dentifrice.

GICs are capable of fluoride uptake, but this property is material dependent. Currently, these materials are releasing the greatest amount of fluoride with respect to dental restorative materials [47].

\section{Conclusions}

The ability to release fluoride was detected initially in all of the materials tested. The self-curing glass-ionomer cement released the greatest amounts of fluoride during the whole study period, except the next day after the treatment with fluoride varnish. Application of fluoride varnish produced an increase of fluoride release for the first 24 hours in case of all materials, followed by a continuous decrease. Results suggest that the use of fluoridated dentifrice would be more effective on long term, due to a possible fluoride uptake capability. Further studies are planned to clarify the fluoride recharging mechanism.

\section{References}

1.DONLY, K.J., INGRAM, C., An in vitro caries inhibition of photopolymerized glass ionomer liners, Journal of Dentistry for Children, 64, 1997, p. 128.

2.DIONYSOPOULOS, P., KOTSANOS, N., PAPADOGIANNIS, Y., KOTSTANTINIDIS, A., Artificial secondary caries around two new Fcontaining restoratives, Operative Dentistry, 23, 1998, p. 81.

3.ATTAR, N., ONEN, A., Fluoride release and uptake characteristics of aesthetic restorative materials, Journal of Oral Rehabilitation, 29, 2002, p. 791.

4.PERRIN, C., PERSIN, M., SARRAZIN, J., A comparison of fluoride release from four glass-ionomer cements, Quintessence Int, 25, no. 9, 1994, p. 603. 
5.RAO, B.S.R., MOOSANI, G.K.R., SHANMUGARAJ, M., KANNAPAN, B., SHANKAR B.S., ISMAIL, P.M.S., Fluoride release and uptake of five dental restoratives from mouthwashes and dentifrices, Journal of International Oral Health, 7, no. 1, 2015, p. 1-5.

6.BERESESCU, F.G., HANCU, V., MUCENIC, S.G, COSARCA, A.S, COMANEANU, R.M, ORMENISAN, A., In vitro Study Regarding the Wearing of Glass lonomer Cements, Mat. Plast., 52, no.2, 2015, p.272278.

7.BALAN, A., SAVIN, C., SANDU, A.V., et al., Study Regarding the Behaviour of Glass-ionomer Cements in Different Acidic Solutions, Mat. Plast., 53, no.1, 2016, p.100-104.

8.BARLEAN, L., COMAN, M., BOBU, L., et al., Comparative Evaluation of a Glassionomer Cement and a Resin Composite Used as Dental Sealants, Mat. Plast., 52, no.4, 2015, p.542-546.

9.CHRISTENSEN, G.J ., Compomers vs. resin-reinforced glass ionomers, J Am Dent Assoc, 128, no. 4, 1997, p. 479.

10.HSE, K.M.Y., LEUNG, S.K., WEI, S.H.Y., Resin-ionomer restorative materials for children: a review, Australian Dental J ournal, 44 (1), 1999, p. 1-11.

11.ANTONIAC, I., SINESCU, C., ANTONIAC, A., Adhesion aspects in biomaterials and medical devices, J Adhes Sci Technol., 30, no. 16, 2016, p.1711-1715.

12.GLASSPOOLE E, A., ERICKSON, R.L., DAVIDSON, C.L., Effect of surface treatments on the bond strength of glass ionomers to enamel, Dent Mater., 18, no.6, 2002, p.454-462.

13.REKHA VISHNU, C., BALOGOPAL VARMA, JAYANTHI, Comparative evaluation of tensile bond strength and microleakage of conventional glass ionomer cement, resin modified glass ionomer cement and compomer: An in vitro study, Contemporary Clinical Dentistry, 3, no.3, 2012, p. 282.

14.CHADWICH, B.L., EVANS, D.J.P., CHADWICH, B.L., EVANS, D.J.P., Restoration of class II cavities in primary molar teeth with conventional and resin modified glass ionomer cements: a systematic review of the literature, European Academy of Paediatric Dentistry ISSN:1818-6300, 8, no. 1, 2007, p.14-21.

15.HANGANU, S.C, ARMENICA, A.O., MURARIU, A.M., et. al., Tribological Behaviour of Three Types of Glass Ionomers Dedicated to Applications in Dentistry, Mat Plast, 50, no.3, 2013, p. 192-196.

16.EARAR, K., PORUMB, A., MATEI, R., CAVALU, S., POPOVICI, R.A., FOCSANEANU, S., DAWOD, N., SACELEANU, A., TODOR, L., The Glass lonomer Cement Reinforced with Silver-Premise in Choosing the Teeth Proposed for Orthodontic Purpose Extraction, Rev. Chim. (Bucharest), 70, no. 1, 2019, p. 324-326.

17.YENGOPAL, V., MICKENAUTSCH, S., BEZERRA, A., LEAL, S., Cariespreventive effect of glass ionomer and resin-based fissure sealants on permanent teeth: a meta-analysis, J Oral Sci, 51, no.3, 2009, p. 373-382.

18.J UMANCA, D., GALUSCAN, A., POPESCU, L.A., GHIORGHE, A., ANDRIAN, S., SINESCU, C., Comparative Study on Available Sealing Materials, Rev. Chim. (Bucharest), 67, no. 2, 2016, p. 241-244.

19.MARINESCU, M., BUTU, L., BORDA, C., ARSENE, D., BUTU, M., Comparative Study of Tensile Behaviour for Layered Polymeric Composite Materials, Mat Plast, 55, no. 3, 2018, p. 279-285.

20.SPANU, P., AMZA, C.G., ABAZA, B.F., Study Regarding the Compressive Properties of Glass Fiber Reinforced Composites, Mat Plast, 55, no. 4, 2018, p. 580-583.

21.21.SAVEANU, C.I., MURARIU, A., CONSTANTIN, O., DRAGOS, 0., GOLOVCENCU, L., Resin Composite Sealant with bis-GMA In vitro and in vivo Study, Mat Plast, 55, no. 4, 2018, p. 669-671.

22.GUGGENBERGER, R., MAY, R., STEFAN, K.P., New trends in glassionomer chemistry, Biomaterials, 19, 1998, p. 479.

23.SULJ AK, J.P., HATIBOVIC-KOFMAN, S., A fluoride release adsorptionrelease system applied to fluoride releasing restorative materials, Quintessence International, 27, 1996, p. 635.

24.MARCAUTEANU, C., NEGRUTIU, M.L., ARDELEAN, L., RUSU, L.C., PODOLEANU, A.GH., Evaluation of the prognosis of compomer Class $\checkmark$ restorations through en face Optical Coherence Tomography, Rev. Chim. (Bucharest), 63, no. 5, 2012, p. 545-547.
25.BORS, A., ANTONIAC, I., COTRUT, C., ANTONIAC, A., SZEKELY, M., Surface analysis of contemporary aesthetic dental filling materials after storage in erosive solutions, Mat. Plast., 53, no. 4, 2016, p.607611.

26.TUCULINA, M.J., RAESCU, M., DASCALU, I.T., POPESCU, M., ANDREESCU, C.F., DAGUCI, C., CUMPATA, C.N., NIMIGEAN, V.R., BANITA, I.M., Indirect pulp capping in young patients: immunohistological study of pulp-dentin complex. Rom J Morphol Embryol, 54, no. 4, 2013, p. 1081-1086.

27.POLL, A., NIMIGEAN, V.R., BADITA, D., BALACEANU, R.A., CISMAS, S.C., PERLEA, P., MORARU, S.A., NIMIGEAN, V., In vivo experimental model for the evaluation of dental implant integration, Rom Biotechnol Lett, 23, no. 2, 2018, p. 13505-13510.

28.POLL, A., MINCULESCU C.A., NIMIGEAN, V.R., BADITA, D., BALACEANU, R.A., PAUN D.L., MORARU S.A., NIMIGEAN V., Experimental model for the study of autogenous mandibular bone grafts integration, Rom Biotechnol Lett, 23, no. 3, 2018, p. 1368113689.

29.NIMIGEAN, V., POLL, A., NIMIGEAN, V.R., MORARU, S.A., BADITA, D.G., PAUN, D.L., The Routine and Specialised Staining for the Histologic Evaluation of Autogenous Mandibular Bone Grafts. An experimental study. Rev Chim (Bucharest), 69, no. 5, 2018, p. 11061109 .

30.ABOUSH, Y.E., TORABZADEH, H., Fluoride release from toothcolored restorative materials: a 12-month report, J Can Dent Assoc, 64, 1998, p. 561.

31.WAHAB, F.K., SHELLIS, R.P., ELDERTON, R.J., Effects of low fluoride concentrations on formation of caries-like lesions in human enamel in a sequential-transfer bacterial system, Arch Oral Biol, 38, 1993, p. 985.

32.FRIEDL, K.H., SCHMALZ, G., HILLER, K.A., SHAMS, M., Resinmodified glass ionomer cements: fluoride release and influence on Streptococcus mutans growth, European Journal of Oral Sciences, 105,1997, p. 81.

33.ATTIN, T., BUCHALLA, W., SIEWERT, C., HELLWIG, E., Flouride release/uptake of polyacid-modified resin composites (compomers) in neutral and acidic buffer solutions, Journal of Oral Rehabilitation, 26, 1999, p. 388.

34.BILLINGTON, R.W., PEARSON, G.J., WILLIAMS, J.A., Uptake of fluoride ions by the glass component of glass ionomer cement, Journal of Dentistry, 35, 2007, p. 452.

35.NICHOLSON, J.W., CZARNECKA, B., Maturation affects fluoride uptake by glass-ionomer dental cements, Dental Materials, 28, 2012, p. 1.

36.DIONYSOPOULOS, D., SFEIKOS, T., TOLIDIS, K., Fluoride release and recharging ability of new dental sealants, Eur Arch Paediatr Dent, 17, 2016, p. 45.

37.TIWARI, S., NANDLAL, B., In vitro Evaluation of Fluoride Release from Hydroxyapatite Reinforced Glass Ionomer with or without Protective Coating. Journal of Clinical and Diagnostic Research, 10, no. 4, 2016, p. 73.

38.DHONT, C.L., DE MAEYER, E.A.P., VERBEECK, R.M.H., Fluoride release from glass ionomer activated with fluoride solutions, J Dent Res, 80, 2001, p. 1402.

39.BILLINGTON, R.W., HADLEY, P.C., TOWLER, M.R., PEARSON, G.J ., WILLIAMS, J.A., Effects of adding sodium and fluoride ions to glass ionomer on its interactions with sodium fluoride solution, Biomaterials, 21, 2000, p. 377.

40.VERBEECK, R.M.H., DE MOOR, R.J.G., VAN EVEN, D.F.J., MARENS, L.C., The Short-term fluoride release of a hand mixed vs. capsulated system of a restorative glass ionomer cement, Journal of Dental Research, 72, no. 3, 1993, p. 577.

41.NIGAM, A.G., J AISWAL, J.N., MURTHY, R.C., PANDEY, R.K., Estimation of Fluoride Release from Various Dental Materials in Different Media - An In Vitro Study. International J ournal of Clinical Pediatric Dentistry, 2, no. 1, 2009, p. 1. 
42.LAMMERS, P.C., BORGGREVEN, J.M., DRIESSENS, F.C., VAN'T HOF, M.A., Acid-susceptibility of lesions in bovine enamel after remineralization in the presence of fluoride and/or carbonate, Caries Res, 26, no. 1, 1992, p. 1.

43.ELIADES, G., KAKABOURA, A., PALAGHIAS, G., Acid-base reaction and fluoride release profiles in visible light-cured polyacidmodified composite restoratives (compomers), Dent Mater, 14, no. 1, 1998, p. 57.

44.HSU, H.M., HUANG, G.F., CHANG, H.H., WANG, Y.L., GUO, M.K., A continuous flow system for assessing fluoride release/uptake of fluoride-containing restorative materials, Dental Materials, 20, 2004, p. 740.
45.AHN, S.) ., LEE, S.J ., LEE, D.Y., LIM, B.S., Effects of different fluoride recharging protocols on fluoride ion release from various orthodontic adhesives, Journal of Dentistry, 39, 2011, p. 196.

46.RAO, A., RAO, A., SUDHA, P., Fluoride rechargability of a non-resin auto-cured glass ionomer cement from a fluoridated dentifrice: an in vitro study, J Indian Soc Pedod Prev Dent., 29, no. 3, 2011, p. 202. 47.HEGDE, M,N., SUSAN, J.J., DARSHANA, D., HEGDE, N.D., Effect of daily fluoride exposure on fluoride release by high strength glass ionomer restorative material used with ART - An in vitro study, Int Res J Pharm, 3, no. 4. 2012, p. 241.

Manuscript received: 20.06 .2019 